University of Nebraska - Lincoln

DigitalCommons@University of Nebraska - Lincoln

Faculty Publications: Department of Entomology

\title{
$2-2018$
}

\section{Resistance in 27 Rice Cultivars to Sugarcane Borer (Lepidoptera: Crambidae)}

F. Correa

C. L. T. Silva

A. P. Pelosi

A. C. S. Almeida

E. A. Heinrichs

See next page for additional authors

Follow this and additional works at: https://digitalcommons.unl.edu/entomologyfacpub

Part of the Agricultural Science Commons, Agronomy and Crop Sciences Commons, Entomology Commons, and the Plant Breeding and Genetics Commons

This Article is brought to you for free and open access by the Entomology, Department of at DigitalCommons@University of Nebraska - Lincoln. It has been accepted for inclusion in Faculty Publications: Department of Entomology by an authorized administrator of DigitalCommons@University of Nebraska - Lincoln. 
Authors

F. Correa, C. L. T. Silva, A. P. Pelosi, A. C. S. Almeida, E. A. Heinrichs, J. A. F. Barrigossi, and F. G. Jesus 
Published in Journal of Economic Entomology 111:1 (February 2018), pp. 422-427;

doi: 10.1093/jee/tox291

Copyright (C 2017 F. Correa, C. L. T. Silva, A. P. Pelosi, A. C. S. Almeida, E. A. Heinrichs, J. A. F. Barrigossi, and F. G. Jesus; published by Oxford University Press on behalf of the Entomological Society of America. Used by permission.

Submitted June 29, 2017; accepted September 19, 2017; published online November 22, 2017.

\title{
Resistance in 27 Rice Cultivars to Sugarcane Borer (Lepidoptera: Crambidae)
}

\author{
F. Correa, ${ }^{1}$ C. L. T. Silva, ${ }^{1}$ A. P. Pelosi,${ }^{1}$ A. C. S. Almeida, ${ }^{1}$ E. A. Heinrichs, ${ }^{2}$
}

J. A. F. Barrigossi, ${ }^{3}$ and F. G. Jesus ${ }^{1}$

1. Federal Goiano Institute, Campus Urutaí, Rodovia Prof. Geraldo Silva Nascimento, Urutaí, Goiás, Brazil

2. Department of Entomology, University of Nebraska-Lincoln, Lincoln, Nebraska, USA

3. Embrapa Rice and Beans, Rodovia GO-462, Santo Antônio de Goiás, Goiás, Brazil

Corresponding author - F. G. Jesus, email flavio.jesus@ifgoiano.edu.br

\begin{abstract}
Rice (Oryza sativa L.) is considered one of the most important crops in the world, and the sugarcane borer, Diatraea saccharalis Fabricius (Lepidoptera: Crambidae), is among the key pests damaging the crop in the Americas. The objective of this work was to identify rice genotypes as a source of resistance to $D$. saccharalis. Rice plants were infested in the greenhouse and subsequently evaluated for damage, larval weight and survival, and stem size. The cultivars "Bonança," "Caripuna," "IR 42," "Canela de Ferro," "SWA Norte," "BR IRGA 409," “Pepita," “Serra Dourada," "Araguaia," "Xingú," "Tangará," and "Soberana" showed antibiosis, antixenosis, or both to D. saccharalis. These cultivars may be used as donor sources in the breeding program and used directly by Brazilian farmers as a component of rice integrated pest management.
\end{abstract}

Keywords: morphological characteristics, sugarcane borer, plant resistance to insect, Oryza sativa 
Rice (Oryza sativa L.), one of the most important crops in the world, is produced in more than 117 countries, and serves as major carbohydrate for more than half of the world population (Mander et al. 2016). Among the insects attacking rice, the sugarcane borer Diatraea saccharalis Fabricius (Lepidoptera: Crambidae) is one of the most important. Cultivated hosts include sugarcane (Saccharum spp.), maize (Zea mays L.), rice (Oryza sativa L.), and sorghum (Sorghum bicolor L. Moench) (Hamm et al. 2012, Joyce et al. 2016). The pest is distributed from the southern United States to Argentina (Sidhu et al. 2013, Joyce et al. 2014).

Larval feeding damage results in the opening of galleries in the stems, resulting in deadhearts (chaffy panicles), aerial rooting, and formation of lateral shoots. Strong winds can cause breakage of stems (Ferreira et al. 2004, Lv et al. 2010). Symptoms of D. saccharalis attack become visible only after the damage occurs (Ferreira and Barrigossi 2002).

Chemical control is commonly used to manage D. saccharalis. However, negative aspects of insecticides use are resistance to insecticides, resurgence of pests, risks to the applicators, contamination of the environment, and costs associated with repeated applications (Sandoval and Senô 2010). Another factor that minimizes the success of chemical control is that stem-boring insects are protected from insecticide applications (Litsinger et al. 2005).

The use of resistant cultivars is compatible with other control tactics in an approach that minimizes the use of insecticides (Sousa et al. 2010, Mikami et al. 2012, Costa et al. 2016). Plant resistance to insects maintains the population density of the pest below the level of economic damage, does not cause adverse effect to the environment, does not incur additional cost, and generally is compatible with other control methods (Lara 1991, Smith 2005, Seifi et al. 2013, Ta-Liao and Chen 2017).

There are three categories of plant resistance to insects: antibiosis occurs when the negative effects of a resistant plant affect the biology of the insect attempting to use that plant as a host; antixenosis affects insect behavior in the choice of the plant for feeding, oviposition, and shelter; and tolerance, which is the ability of the plant to resist or recover from insect damage due to the production of new vegetative or reproductive structures (Lara 1991, Smith 2005, Seifi et al. 2013).

The screening of rice cultivars to identify genetic resistance to the stem borer is important because the plants can be used as donor sources in breeding programs or used directly by famers (Sidhu et al. 2013). However, studies to identify sources of resistance in Brazil are limited, and few rice genotypes with resistance to $D$. saccharalis have been identified. An antibiosis, antixenosis component, or both was observed in the rice genotype $\mathrm{Ku}$ 94-2, which causes high larval mortality in D. saccharalis, and tolerance was observed in BR IRGA 417 and MTU 15, as indicated by the production of new tillers after pest damage occurred (Nascimento and Barrigossi 2014). Nascimento et al. (2015) identified tolerance to $D$. saccharalis in the genotypes Chiang, Tsao Pai Ku, and IR 40.

The objective of this study was to identify additional sources of resistance to $D$. saccharalis, aiming at the effective use of resistance as a component in an integrated pest management for $D$. saccharalis in rice crop. 


\section{Materials and Methods}

\section{Experimental conditions}

The experiments were carried out under greenhouse conditions at the Agricultural Entomology Laboratory of the Goiano Federal Institute - Campus Urutaí (Urutaí, Goiás, Brazil). Experiments were conducted twice (November 2015 to February 2016 and February to July 2016).

Twenty-seven rice genotypes were used (Table 1). These genotypes are maintained at the Embrapa Rice and Beans center, located in Santo Antônio de Goiás, Goiás, Brazil $\left(16^{\circ} 40^{\prime} 43^{\prime \prime} \mathrm{S} ; 49^{\circ} 15^{\prime} 14^{\prime \prime} \mathrm{W}\right)$. Seeds were planted in trays of 200 cells containing substrate Maxfertil (Maxfertil, Pouso Redondo, Santa Catarina, Brazil). After $15 \mathrm{~d}$, seedlings were transplanted to plastic pots of 5 liters, containing sand, earth, and bovine manure (1:2:1, by volume).

The cultural treatments were carried out according to recommendations, except for the application of insecticides. Soil chemical analyses were conducted and the fertilization was according to the recommendation of Souza and Lobato (2004).

\section{Plant Infestation and Phenotypic Evaluation}

Eggs of D. saccharalis used in the experiments were obtained from Biocana, Itumbiara, Goiás, Brazil, where mass rearing is maintained on artificial diet (Vacari et al. 2012). The egg masses were kept in plastic cups $(300 \mathrm{ml})$ in a controlled environment $\left(25 \pm 2^{\circ} \mathrm{C}\right.$, photoperiod of 12:12 (L:D) h, and 70\% RH) until hatching.

At $45 \mathrm{~d}$ after transplanting, the plants were infested with first instar larvae of $D$. saccharalis. Plants were thinned to three stems per plant. Eppendorf tubes, containing two newly hatched larvae, were placed in the sheaths of the plants at a proportion of two larvae per rice stem. The plants were protected by an organdy fabric cage to prevent larval escape and attack by natural enemies.

Thirty days after the infestation, the plants were cut close to the ground and taken to the laboratory, where the stems were analyzed. The following phenotypic variables were evaluated: number of stems with no damage (NSN), number of damaged stem (NDS), percentage of damaged stems (PDS), number of live larvae per stem (NLL), average weight of larvae (AWL), and internal diameter (ID) and external diameter (ED). ID and ED were determined with a digital pachymeter (Absolute - Digimatic) (Mitutoyo, Suzano, São Paulo, Brazil), measuring three stems per replication and averaged to obtain the results. The surviving larvae were removed from the stem and weighed on an analytical balance (Marte AY220) (Marte Científica, São Paulo, São Paulo, Brazil). The experimental design was completely randomized with five replicates. 
Table 1. Rice accessions screened for resistance to sugarcane borer, Embrapa Rice and Beans genebank, Urutaí, Goiás, Brazil

\begin{tabular}{|c|c|c|c|}
\hline Cultivar & ID no. & Pedigree & Origin \\
\hline Araguaia & CNA 4206 & IAC-47/TOS 2578/7-4-2-3-B2 2578/7-4-2-3-B2, r & Nigeria \\
\hline Bonança & CNA 8172 & $\begin{array}{l}\text { CT7244-9-2-1-52-1/CT7232-5-3-7-2-1P // } \\
\text { CT6196-33-11-1-3-AP }\end{array}$ & Colombia \\
\hline BR IRGA 409 & BRA00007108-4 & IR930-2/IR665-31-2-4 & Brazil \\
\hline BRS Esmeralda & BRA032048 & $\begin{array}{l}\text { CNAx4909-68-M-M2-PY2/BRS Primavera/ } \\
\text { M2-PY2 }\end{array}$ & Brazil \\
\hline BRS Soberana & CNA 8711 & Cuiabana/CNAx 1235-8-3 // CNA 6673 & Brazil \\
\hline BRSGO Serra Dourada & BRA 01653 & Katy/Confiança & Brazil \\
\hline BRSMT Vencedora & CNAs8817 & CT6516-23-10-1-1-3-B/CNA6886 & Brazil \\
\hline Cabaçú & BGA 3281 & Mutação IRAT-79 & French Guiana \\
\hline Canela de Ferro & BGA 011523 & - & Brazil \\
\hline Caripuna & BRA 00006866-8 & - & Colombia \\
\hline Carisma & CNA 8305 & СТ7244-9-1-5-3/СТ6196-33-11-1-3 & Colombia \\
\hline Centro América & CNA 4122 & IAC-25/63-83 & Brazil \\
\hline Confiança & CNA 0007706 & IAC $164 /$ Rio Verde & Brazil \\
\hline Curinga & CNA 8812 & $\begin{array}{l}\text { CT9978-12-2-2P-4/CT10037-56-4-M-4-1-p-1 } \\
\text { // P5589-1-1-3P-1 1P/CT9356 } \\
\text { 4/CT10037-56-4-M-4-1-p-1 // P5589-1-1-3P- } \\
\text { 1-1P/СT9356 }\end{array}$ & Brazil \\
\hline Guarani & CNA 4121 & IAC-25/63-83 & Brazil \\
\hline IR 40 & BGA005471 & - & Philippines \\
\hline IR 42 & BGA 3271 & - & Philippines \\
\hline Monarca & CNAs9045 & $\begin{array}{l}\text { CNA7914/CNAx3031-13-B-1 1//CNA7455/ } \\
\text { Colombia } 1\end{array}$ & Brazil \\
\hline Pepita & CNAs 9019 & CNA7680/CNA7726 & Brazil \\
\hline Progresso & BRA00006633-2 & - & Brazil \\
\hline Rio Paraguai & CNA 4140 & IAC-47/63-83 & Brazil \\
\hline Rio Paranaíba & BRA00002857-1 & IAC-47/63-83 & Brazil \\
\hline Rio Verde & CNA 5342 & Colômbia 1/M-312A & Brazil \\
\hline Sertaneja & CNAs 9025 & $\begin{array}{l}\text { Carajás // IAC 165²/Labelle //// Três Marias/ } \\
\text { IAC } 25^{3} \text { /// A8-204-1/Guarani // IRAT } 216\end{array}$ & Brazil \\
\hline SWA Norte & BRA 00010135-2 & - & Brazil \\
\hline Tangara & CNA 5180 & IAC 25/IRAT 13 & Brazil \\
\hline Xingú & BGA 006030 & IAC - 47/IRAT 13 & Brazil \\
\hline
\end{tabular}

\section{Statistical Analysis}

The results were submitted to multivariate analysis of variance (MANOVA). There was a significant effect $(P<0.05)$ of cultivars when the means were compared by the Scott-Knott test at $5 \%$ probability (R Core Team 2017). A cluster analysis was performed using the Hierarquical Cluster Analysis - UPGMA method based on the Mahalanobis generalized distance to group cultivars by their level of resistance. A Canonical Discriminant Analysis - CVA was performed to study the distance relationship between cultivars as well as their 
relationship with the resistance variables NSN, NDS, PDS (ratio of stem number damaged by total stem number), NLL, AWL, ID, and ED (R Core Team 2017).

$t$-Test was used for evaluating the significance of the phenotypic correlation among all variables. All analyses were performed using R software, version 3.2.2 (R Core Team 2017).

\section{Results}

The phenotypic response of rice cultivars to $D$. saccharalis differed in NDS ( $F=2.38$; $\mathrm{df}=26$; $P=0.0010)$, AWL $(F=1.63 ; \mathrm{df}=26 ; P=0.0438), \mathrm{ID}(F=2.31 ; \mathrm{df}=26 ; P=0.0015)$, and ED $(F=4.77 ; \mathrm{df}=26 ; P<0.0005)$ (Table 2$)$.

The lowest mean number of damaged stems was observed in the cultivars "Bonança," "Cabaçú," "Caripuna," "IR 42," “Canela de Ferro," "SWA Norte," “BRS IRGA 409," "Pepita," "Serra Dourada," “Araguaia," "Xingú,," “Curinga," "Guarani," "Progresso," “Carisma," and "Rio Verde." The highest live larvae weight was observed on the cultivar "Caripuna." The genotypes "IR 40," "Tangará," "Rio Paraguai," "SWA Norte," "Canela de Ferro," "Soberana," "Caripuna," “Guarani," “IR 42," "Araguaia," "Bonança," "Progresso," "BR IRGA 409," and "Rio Paranaíba" had the smallest IDs. "IR 40," "Soberana," and "BR IRGA 409" had the smallest EDs while "Tangará," "IR 42," “Bonança," “Guarani," "Carisma," "BRS Esmeralda," "Caripuna," "Vencedora," "Rio Paranaíba," and "SWA Norte" had intermediate values (Table 2).

There was a positive correlation between the NLL and ED, AWL and ID (Table 3), indicating that plants with a large external stem diameter are propitious for the development of the sugarcane borer. Plants with smaller external stem diameter were associated with lower D. saccharalis weights (Table 2).

Varieties were grouped by level of resistance, based on the UPGMA analysis (Fig. 1). Groups VI and III presented moderate resistance, those grouped in I are susceptible, and groups II, V, and IV presented high susceptibility to D. saccharalis. This was supported by the canonical variable analysis depicted in Figure 2. The first canonical variable explained $38.7 \%$ of the total parameters evaluated for the seven characteristics described in the 27 rice genotypes for $D$. saccharalis.

Both multivariate methods provided similar results regarding the resistance groupings. The "Canela de Ferro" cultivar that appears isolated in the CVA analysis also appears in group III in the UPGMA grouping that compose the genotypes with moderate resistance. Also the genotype "Progresso" that was in group VI is isolated in the CVA analysis and presents the level of moderate resistance to $D$. saccharalis.

The "IR 40" genotype was isolated in both analyses and can be classified as high susceptibility to the stem borer. The genotype "BR IRGA 409" that was in group V is isolated in the CVA analysis and presents the level of high susceptibility to D. saccharalis. 
CORREA ET AL., JOURNAL OF ECONOMIC ENTOMOLOGY 111 (2018)

Table 2. Evaluation of 27 rice cultivars for resistance to D. saccharalis, Urutaí, Goiás, Brazil

\begin{tabular}{|c|c|c|c|c|c|c|c|}
\hline Genotype & NDS & PDS & NSN & NLL & AWL & ID & ED \\
\hline Araguaia & $1.4 \mathrm{~b}$ & 35.00 & 2.2 & 1.2 & $0.034 \mathrm{~b}$ & $1.93 \mathrm{~b}$ & $6.39 a$ \\
\hline Bonança & $0.6 \mathrm{~b}$ & 19.99 & 2.4 & 1.0 & $0.057 \mathrm{~b}$ & $1.93 \mathrm{~b}$ & $4.93 \mathrm{~b}$ \\
\hline BRS Esmeralda & $2.2 \mathrm{a}$ & 62.00 & 1.6 & 1.4 & $0.055 \mathrm{~b}$ & $2.06 \mathrm{a}$ & $5.14 \mathrm{~b}$ \\
\hline BR IRGA 409 & $1.2 \mathrm{~b}$ & 36.66 & 2.0 & 1.4 & $0.043 \mathrm{~b}$ & $1.95 \mathrm{~b}$ & $4.32 \mathrm{c}$ \\
\hline Cabaçú & $0.6 \mathrm{~b}$ & 15.00 & 3.0 & 1.6 & $0.037 \mathrm{~b}$ & $2.26 \mathrm{a}$ & $6.06 \mathrm{a}$ \\
\hline Canela de Ferro & $1.0 \mathrm{~b}$ & 31.66 & 2.2 & 1.8 & $0.050 \mathrm{~b}$ & $1.75 \mathrm{~b}$ & $6.38 \mathrm{a}$ \\
\hline Caripuna & $0.6 \mathrm{~b}$ & 18.33 & 2.8 & 1.0 & $0.073 \mathrm{a}$ & $1.83 \mathrm{~b}$ & $5.15 \mathrm{~b}$ \\
\hline Carisma & $1.8 \mathrm{~b}$ & 58.33 & 1.6 & 0.8 & $0.039 \mathrm{~b}$ & $2.26 \mathrm{a}$ & $5.11 \mathrm{~b}$ \\
\hline Centro América & $2.8 \mathrm{a}$ & 83.00 & 0.8 & 2.6 & $0.033 \mathrm{~b}$ & $2.29 \mathrm{a}$ & $5.81 \mathrm{a}$ \\
\hline Confiança & $2.2 \mathrm{a}$ & 52.00 & 2.0 & 1.0 & $0.037 \mathrm{~b}$ & $2.33 \mathrm{a}$ & $6.26 \mathrm{a}$ \\
\hline Curinga & $1.6 \mathrm{~b}$ & 46.66 & 1.8 & 1.2 & $0.031 \mathrm{~b}$ & $2.21 \mathrm{a}$ & $5.71 \mathrm{a}$ \\
\hline Guarani & $1.6 \mathrm{~b}$ & 46.66 & 2.0 & 0.8 & $0.037 \mathrm{~b}$ & $1.87 \mathrm{~b}$ & $4.94 \mathrm{~b}$ \\
\hline IR 40 & $2.0 \mathrm{a}$ & 50.00 & 1.8 & 1.0 & $0.035 \mathrm{~b}$ & $1.60 \mathrm{~b}$ & $3.53 \mathrm{c}$ \\
\hline IR 42 & $0.6 \mathrm{~b}$ & 26.66 & 2.2 & 0.6 & $0.038 \mathrm{~b}$ & $1.87 \mathrm{~b}$ & $4.78 \mathrm{~b}$ \\
\hline Monarca & $3.2 \mathrm{a}$ & 80.00 & 0.8 & 2.4 & $0.058 \mathrm{~b}$ & $2.26 \mathrm{a}$ & $5.67 \mathrm{a}$ \\
\hline Pepita & $1.2 \mathrm{~b}$ & 36.66 & 2.4 & 1.0 & $0.051 \mathrm{~b}$ & $2.05 \mathrm{a}$ & $5.67 \mathrm{a}$ \\
\hline Progresso & $1.6 \mathrm{~b}$ & 36.66 & 2.8 & 1.4 & $0.053 \mathrm{~b}$ & $1.93 \mathrm{~b}$ & $5.76 \mathrm{a}$ \\
\hline Rio Paraguai & $2.2 \mathrm{a}$ & 73.33 & 0.8 & 2.2 & $0.042 \mathrm{~b}$ & $1.66 \mathrm{~b}$ & $5.55 \mathrm{a}$ \\
\hline Rio Paranaíba & $2.4 \mathrm{a}$ & 66.57 & 1.8 & 1.4 & $0.047 \mathrm{~b}$ & $1.99 \mathrm{~b}$ & $5.20 \mathrm{~b}$ \\
\hline Rio Verde & $1.8 \mathrm{~b}$ & 58.33 & 1.6 & 1.0 & $0.040 \mathrm{~b}$ & $2.45 \mathrm{a}$ & $6.24 \mathrm{a}$ \\
\hline Serra Dourada & $1.2 \mathrm{~b}$ & 35.00 & 2.2 & 1.6 & $0.037 \mathrm{~b}$ & $2.63 \mathrm{a}$ & $6.39 \mathrm{a}$ \\
\hline Sertaneja & $2.4 \mathrm{a}$ & 67.05 & 1.8 & 1.4 & $0.026 \mathrm{~b}$ & $2.14 \mathrm{a}$ & $6.63 \mathrm{a}$ \\
\hline Soberana & $2.4 \mathrm{a}$ & 70.00 & 1.0 & 0.6 & $0.041 \mathrm{~b}$ & $1.79 \mathrm{~b}$ & $4.23 \mathrm{c}$ \\
\hline SWA Norte & $1.0 \mathrm{~b}$ & 30.00 & 2.4 & 0.4 & $0.051 \mathrm{~b}$ & $1.72 \mathrm{~b}$ & $5.21 \mathrm{~b}$ \\
\hline Tangara & $2.6 \mathrm{a}$ & 57.00 & 2.0 & 1.0 & $0.025 \mathrm{~b}$ & $1.65 \mathrm{~b}$ & $4.66 \mathrm{~b}$ \\
\hline Vencedora & $3.6 \mathrm{a}$ & 92.00 & 0.4 & 0.6 & $0.052 \mathrm{~b}$ & $2.25 \mathrm{a}$ & $5.17 \mathrm{~b}$ \\
\hline Xingú & $1.4 \mathrm{~b}$ & 41.66 & 1.8 & 1.4 & $0.060 \mathrm{~b}$ & $2.16 \mathrm{a}$ & $5.90 \mathrm{a}$ \\
\hline $\mathrm{F}$ & 2.39 & 1.11 & 1.08 & 0.88 & 1.63 & 2.31 & 4.78 \\
\hline$P$ Value & 0.0010 & 0.3352 & 0.3411 & 0.6307 & 0.0438 & 0.0015 & $<0.0005$ \\
\hline
\end{tabular}

Means followed by the same letter, within a column, do not differ significantly by the Scott-Knott test at the $5 \%$ probability.

NDS (Number of damaged stem), PDS (percentage of damaged stems), NSN (number of stems with no damage), NLL (number of live larvae per stem), AWL (average weight of larvae), ID (internal diameter), and ID (external diameter). 
Table 3. Values of $P$ (lower triangle) and correlation coefficients (upper triangle) between the characteristics of resistance to $D$. saccharalis on 27 rice cultivars, Urutaí, Goiás, Brazil

\begin{tabular}{lccccccc}
\hline Variables & NDS & PDS & NSN & NLL & AWL & ID & ED \\
\hline NDS & - & -0.255 & $0.775^{* *}$ & 0.266 & -0.239 & -0.024 & -0.056 \\
PDS & 0.1910 & - & -0.147 & -0.225 & -0.339 & -0.096 & -0.184 \\
NSN & $<0.0005$ & 0.4564 & - & -0.329 & 0.212 & 0.065 & 0.165 \\
NLL & 0.1712 & 0.2503 & 0.0872 & - & -0.228 & 0.028 & $0.380^{*}$ \\
AWL & 0.2209 & 0.7750 & 0.2780 & 0.2433 & - & $0.646^{* *}$ & -0.128 \\
ID & 0.9019 & 0.6260 & 0.7389 & 0.8840 & $<0.0005$ & - & 0.338 \\
ED & 0.7749 & 0.3474 & 0.4000 & 0.0457 & 0.5148 & 0.0785 & - \\
\hline
\end{tabular}

NDS (Number of damaged stem), PDS (percentage of damaged stems), NSN (number of stems with no damage), NLL (number of live larvae per stem), AWL (average weight of larvae), ID (internal diameter), and ID (external diameter). ${ }^{* *}$ and ${ }^{*}$ limits of 1 and $5 \%$ of probability.

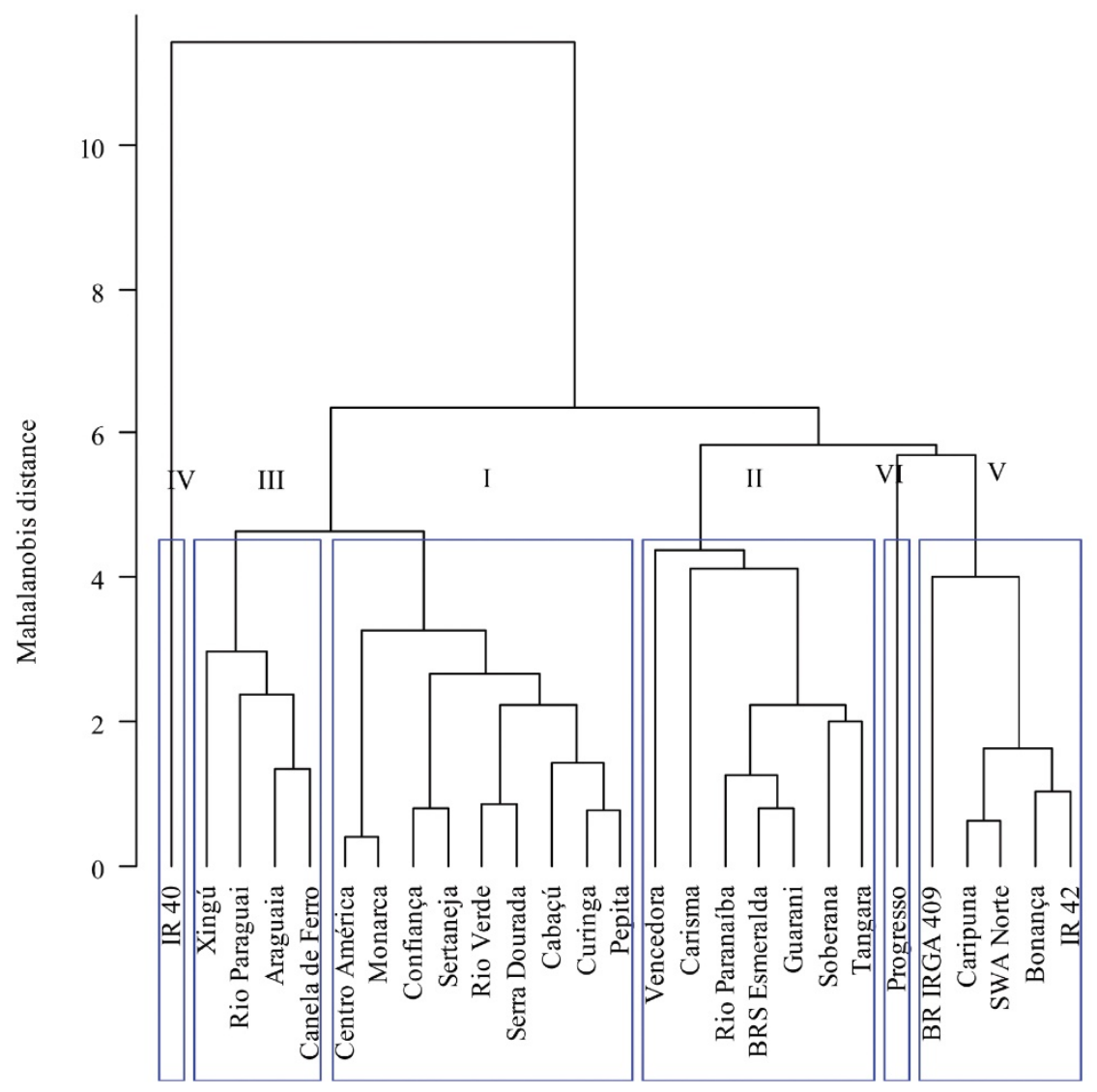

Figure 1. Dendrogram resulting from the multivariate grouping analyses, using the UPGMA method, based on the Mahalanobis distance, from the NSN, NDS, PDS, NLL, AML, ID, and ED on 27 rice cultivars, Urutaí, Goiás, Brazil. 


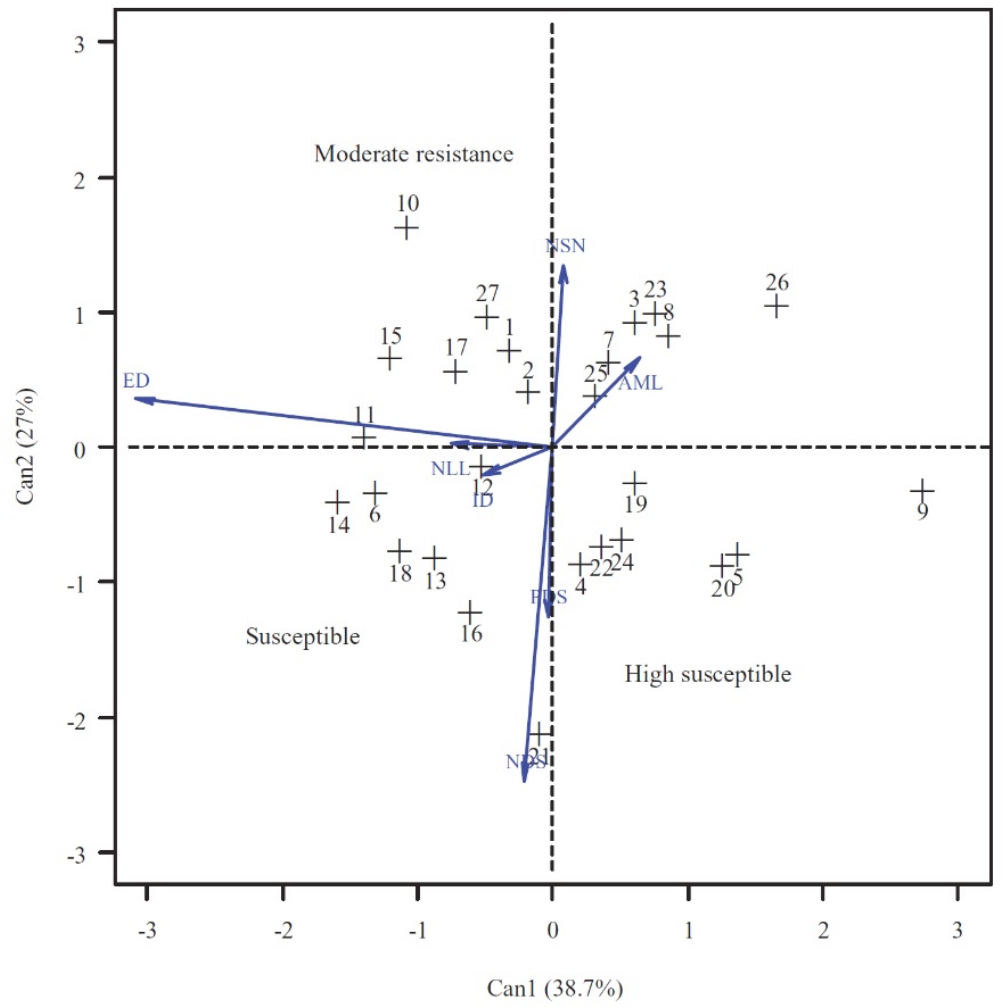

Figure 2. Biplot containing average scores of 27 rice cultivars for the first two canonical variables. Evaluated characters: NDS, PDS, NSN, NLL, AWL, ID, and ED. Cultivars: (1) Rio Paraguai, (2) Pepita, (3) Caripuna, (4) BRS Esmeralda, (5) Soberana, (6) Rio Verde, (7) SWA Norte, (8) IR 42, (9) IR 40, (10) Canela de Ferro, (11) Serra Dourada, (12) Curinga, (13) Centro América, (14) Sertaneja, (15) Araguaia, (16) Monarca, (17) Cabaçú, (18), Confiança, (19) Guarani, (20) Tangara, (21) Vencedora, (22) Rio Paranaíba, (23) Bonança, (24) Carisma, (25) Progresso, (26) BR IRGA 409, and (27) Xingú. Urutaí, Goiás, Brazil.

\section{Discussion}

Through the morphological characteristics and damage caused by D. saccharalis in rice cultivars, it is possible to characterize resistance. The cultivars with the lowest number of stems damaged, i.e., "Bonança," "Cabaçú," "Caripuna," “IR 42," “Canela de Ferro," "SWA Norte," "BR IRGA 409," "Pepita," "Serra Dourada," "Araguaia," and "Xingú," may have antibiosis, antioxenosis resistance, or both. Likewise, cultivars with the smallest internal diameters, i.e., "Tangará," "Rio Paranaíba," “SWA Norte," “Canela de Ferro," "Soberana," "Caripuna," "Guarani," “IR 42," “Araguaia," “Bonança," "Progresso," “BR IRGA 409," and "Rio Paraguai" may exert antibiosis, antixenosis resistance, or both.

The univariate (Tables 2 and 3) and multivariate analyses (Figs. 1 and 2) indicated that the cultivars "Bonança," "Caripuna," "IR 42," "Canela de Ferro," "SWA Norte," "BR IRGA 409," "Araguaia," "Xingú," and "Rio Paraguai" are resistant to D. saccharalis through the antixenosis, antibiosis resistance, or both. These cultivars showed the lowest values of the 
ID of the stem, except the cultivar "Xingú." The cultivar "IR 40" showed the low value of the ID of the stem; however, this cultivar was classified as high susceptible due the higher number of damaged stem. This cultivar may have others allelochemicals or morphological characteristics such as tissue thickness, favorable to the insect penetration in the stem of the plant (Smith 2005).

The narrow internal stem diameter have been associated with sugarcane borer resistance. Nascimento and Barrigossi (2014) observed that rice cultivars with ED and ID of the stem $>2.5 \mathrm{~mm}$ were susceptible to $D$. saccharalis. Narrow stems prevent larvae from developing normally inside the plant (Martins et al. 1981). This is supported by the positive correlation of the larval weight and ID of the stem in this study (Table 2).

The cultivar Xingú may have other resistance traits, such as low protein content (Arnason et al. 1993, Cunha et al. 1999), the presence of amylase inhibitors (Marsaro Júnior et al. 2005) or silicon content in the plant, and stem sclerotization. Such characteristics may confer resistance to other rice stem borers (Chaudhary et al. 1984). Van and Guan (1959) observed high larval mortality of Chillo suppressalis (Walker) (Lepidoptera: Pyralidae) in rice genotypes of Oryzae ridleyi (Hooka) due to the high sclerotization of the stems of these plants.

Two multivariate analysis resulted in six cultivar groups differing in sugarcane borer resistance with different degrees of resistance. Plants can express different degrees of resistance in response to pest damage. The degrees are classified as immunity, high and moderate resistance, susceptibility, and high susceptibility (Smith 2005, Seifi et al. 2013).

The results presented by the UPGMA grouping method demonstrate that the cultivars grouped in I are susceptible; II, V, and IV showed high susceptibility; and VI and III are moderate resistant to $D$. saccharalis. These cultivars with moderate resistance to $D$. saccharalis are promising for use in breeding programs aimed at resistance to sugarcane borer or can be used directly by rice farmers in Brazil (Smith 2005, Seifi et al. 2013).

The cultivar "Canela de Ferro" has been classified as resistant to D. saccharalis by other authors (Nascimento and Barrigossi 2014, Nascimento et al. 2015), which may be related to the narrow stem diameters expressed in this cultivar. Ferreira et al. (2000) observed tolerance in the cultivars "Bonança" and "Carisma" due to the higher number of tillers in these plants and higher quality of grain yield after D. saccharalis infestation. It is noted in this work that these cultivars were classified as highly susceptible to sugarcane borer; however, we did not quantify yield components. This shows the importance of resistance in screening of genotypes to avoid missing sources of resistance. Thus, future studies should include measurement of tolerance.

The identification of cultivars with moderate resistance to $D$. saccharalis will benefit to farmers by improving grain yield in comparison to susceptible cultivars as well as reducing the use of insecticides required to control sugarcane borer in the rice crop.

According to the morphological traits of fewer damaged stems and smaller internal diameters (Table 2), these cultivars have antibiosis, antixenosis, or both to D. saccharalis. These cultivars may be used as donor sources in the breeding program or they may be used directly by Brazilian farmers as a component in integrated pest management in the rice crop. These cultivars need to be further evaluated under field conditions to verify the level of resistance to $D$. saccharalis. 
The multivariate analysis (UPGMA cluster analysis and CVA analysis) were efficient in the identification of resistant levels in rice genotypes and could be complementary to univariate analysis.

Acknowledgments - This study was partially supported by a National Council of Research and Technology of Brazil (CNPq) grant 311280/2015-3 to F.G.J. We also thank the Instituto Federal Goiano - Campus Urutaí for support.

\section{References Cited}

Arnason, J. T., J. D. H. Lambert, J. Gale, J. Mihm, M. Bjarnason, D. Jewell, J. A. Serratos, J. FregeauReid, and L. Pietrzak. 1993. Is "Quality Protein" Maize more susceptible than normal varieties to attack by the Maize Weevil, Sitophilus zeamais? Postharvest Biol. Technol. 2: 349-358.

Chaudhary, R. C., G. S. Khush, and E. A. Heinrichs. 1984. Varietal resistance to rice stem-borers in Asia. Int. J. Trop. Insect Sci. 5: 447-463.

Costa, D. C. S., A. C. S. Almeida, M. S. Araújo, E. A. Heinrichs, M. C. Lacerda, J. A. F. Barrigossi, and F. G. Jesus. 2016. Resistance of rice varieties to Sitophilus oryzae (Coleoptera: Curculionidae). Fla. Entomol. 99: 769-773.

Cunha, A. A., D. Rézio, M. C. R. Silva, and A. H. Garcia. 1999. Níveis de resistência de populações de milho de alta qualidade proteica ao Sitophilus zeamais. Pesqui. Agropecu. Trop. 29: 43-47.

Ferreira, E., and J. A. F. Barrigossi. 2002. Orientações para o controle da broca-do-colmo em arroz. Comunicado Técnico. Embrapa Arroz e Feijão, Santo Antônio de Goiás, Goiás.

Ferreira, M. E., M. I. O. Pentedo, C. Brondani, A. Belo, M. A. Ferreira, and P. H. N. Rangel. 2000. Caracterización y uso de marcadores RAPD y microsatélites (SSR) en el monitoreo del programa de mejoramiento poblacional en arroz. In: E. P. Guimarães (Ed.), Avances en el mejoramiento poblacional en arroz. Embrapa Arroz e Feijão, Santo Antônio de Goiás, Goiás.

Ferreira, E., J. A. F. Barrigossi, E. M. Castro, and A. B. Santos. 2004. Perdas de produção pela broca-docolmo (Diatraea saccharalis Fabr. 1794) (Lepidoptera: Pyralidae) em genótipos de arroz de terras altas. Pesqui. Agropecu. Trop. 34: 99-103.

Hamm, J. C., J. K. Sidhu, M. J. Stout, N. A. Hummel, and T. E. Regan. 2012. Oviposition behavior of Diatraea saccharalis (Lepidoptera: Crambidae) on different rice cultivars in Louisiana. Environ. Entomol. 41: 571-577.

Joyce, A. L., W. H. White, G. S. Nuessly, M. A. Solis, S. J. Scheffer, M. L. Lewis, and R. F. Medina. 2014. Geographic population structure of the sugarcane borer, Diatraea saccharalis (F.) (Lepidoptera: Crambidae), in the Southern United States. PLoS One. 9: 110036.

Joyce, A. L., M. S. Chicas, L. S. Cervantes, M. Paniagua, S. J. Scheffer, and M. A. Solis. 2016. Hostplant associated genetic divergence of two Diatraea spp. (Lepidoptera: Crambidae) stemborers on novel crop plants. Ecol. Evol. 6: 8632-8644.

Lara, F. M. 1991. Princípios de resistência de plantas a insetos. Ícone, São Paulo.

Litsinger, J. A., J. P. Bandong, B. L. Canapi, C. G. Dela Cruz, P. C. Pantua, A. L. Alviola, and E. H. Batay-An. 2005. Evaluation of action thresholds for chronic rice insect pests in the Philippines. I. Less frequently occurring pests and overall assessment. Int. J. Pest Manage. 51: 45-61.

Lv, J., L. T. Wilson, J. M. Beuzelin, and T. E. Reagan. 2010. Rice tillering and yield as affected by artificial and sugarcane borer (Lepidoptera: Crambidae) culm injury. Environ. Entomol. 39: 528-534.

Mander, A., A. Anandan, S. K. Pradhan, and E. Pandit. 2016. Rice grain nutritional traits and their enhancement using relevant genes and QTLs through advanced approaches. SpringerPlus. 5: 1-18. 
Marsaro Júnior, A. L., S. M. Lazzari, E. L. Figueira, and E. Y. Hirooka. 2005. Inibidores de amilase em híbridos de milho como fator de resistência a Sitophilus zeamais (Coleoptera: Curculionidae). Neotrop. Entomol. 34: 443-450.

Martins, J. F. S., N. V. Tan, and B. I. S. Pinheiro. 1981. Resistencia de arroz de sequeiro á broca-docolmo e sua associação com características morfológicas das plantas. Pesqui. Agropecu. Bras. 16: 187-192.

Mikami, A. Y., V. Carpentieri-Pípolo, M. U. Ventura. 2012. Resistance of maize landraces to the maize weevil Sitophilus zeamais (Coleoptera: Curculionidae). Neotrop. Entomol. 41: 404-408.

Nascimento, J. B., and J. A. F. Barrigossi. 2014. Responses of rice mini-core collection accessions to damage by Diatraea saccharalis (Fabricius) stem borer. Agric.Sci. 5: 776-784.

Nascimento, J. B., J. A. F. Barrigossi, T. C. O. Borba, J. F. S. Martins, P. M. Fernandes, and R. N. Mello. 2015. Evaluation rice genotypes for sugarcane borer resistance using phenotypic methods and molecular markers. Crop Prot. 67: 43-51.

R Core Team. 2017. R: the R project for statistical computing. Vienna: R Foundation for Statistical Computing. Version 3.3.3.

Sandoval, S. S., and K. C. A. Senô. 2010. Comportamento e controle da Diatraea saccharalis na cultura da cana-de-açúcar. Nucleus 7: 1-16.

Seifi, A., R. G. F. Visser, and Y. Bai. 2013. How to effectively deploy plant resistances to pests and pathogens in crop breeding. Euphytica. 190: 321-334.

Sidhu, J. K., M. J. Stout, and D. C. Blouin. 2013. Performance and preference of sugarcane borer, Diatraea saccharalis, on rice cultivars. Entomol. Exp. Appl. 149: 67-76.

Smith, C. M. 2005. Plant resistance to arthropods: molecular and conventional approaches. Springer, Dordrecht, The Netherlands.

Sousa, J. R., J. A. F. Barrigossi, A. L. Boiça Júnior, K. K. M. Gonçalves, E. R. S. Torres, and J. M. Mondengo. 2010. Avaliação de resistência em variedades de arroz (Oryza sativa 1.) ao ataque do Sitophilus oryzae linnaeus, 1763 (coleoptera: curculionidae). Nucleus 7: 1-8.

Souza, D. M. G., and E. Lobato. 2004. Cerrado: Correção do solo e adubação. Embrapa Informação Tecnológica, Brasília - DF.

Ta-Liao, C., and C. Chen. 2017. Oviposition preference and larval performance of Cnaphalocrocis medinalis (Lepidoptera: Pyralidae) on rice genotypes. J. Econ. Entomol. 110: 1291-1297.

Vacari, A. M., G. Souza Genovez, V. L. Laurentis, and S. A. Bortoli. 2012. Protein source in Diatraea saccharalis diet and its impact on production and quality control of Cotesia flavipes. Bragantia 71: 355-361.

Van, T. K., and G. K. Guan. 1959. The resistance of Oryza ridleyi Hook to paddy stem borer attack. Malays. Agric. J. 42: 207-210. 